\title{
LEAN MANUFACTURING PROCESS PLANNING FOR 5 AXES CNC DRIVEN MILLING MACHINE
}

\author{
Sándor Bodzás ${ }^{1 \boxminus}$, Béla Krakkó²
}

$1 \Xi$ University of Debrecen, Faculty of Engineering, Department of Mechanical Engineering, 4028 Debrecen Ótemető str. 2-4, Hungary, email: bodzassandor@eng.unideb.hu

${ }^{2}$ Industrial Engineer

Submitted: 2017-12-14 / Accepted: 2018-03-19 / Published: 2018-03-29

\section{ABSTRACT}

The aim of this publication is to determine the OEE (Overall Equipment Efficiency) indicator for 5 axes milling machine found at Diehl Aircabin Hungary Ltd. for the present and future state. Based on this value, the utilization of the machine for the given production amount can be calculated. With the optimal choice of the right production parameters (the number of cuts, feeding, depth of cut, etc.) greater productivity can be achieved i.e. the machine main time (time of cutting) will be less. The possibilities of the reduction of the machine time will be analysed and calculated. Setting of the appropriate technological parameters the machine main time could be decreased. The calculation of the machine main time will be determined for the most frequent manufacturing technologies.

KEYWORDS: OEE value, production planning, LEAN, milling machine

\section{Introduction}

LEAN is an organizational company conducting system which aims to produce its products and services by the most economical way. A LEAN company targets its activities on the customers' needs, and what they perceive as valuable. Those things which are not of value for the customer, and for which they are not willing to pay, LEAN system takes as loss, and increases the efficiency of the processes by ceasing these losses or reducing them to the maximum [4], [5].

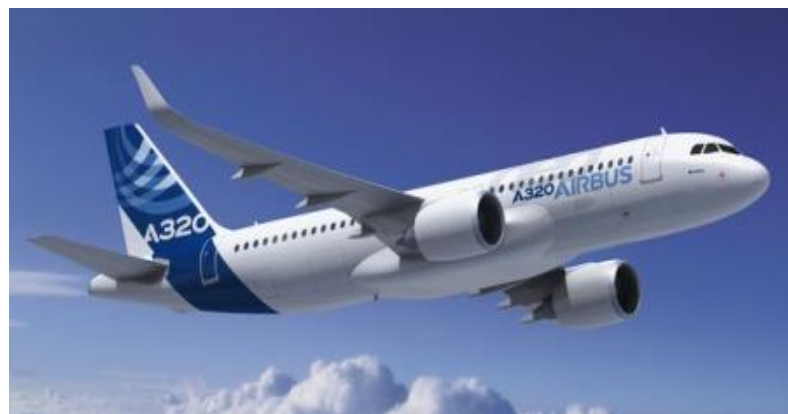

a) Airbus A320 type Single Aisle

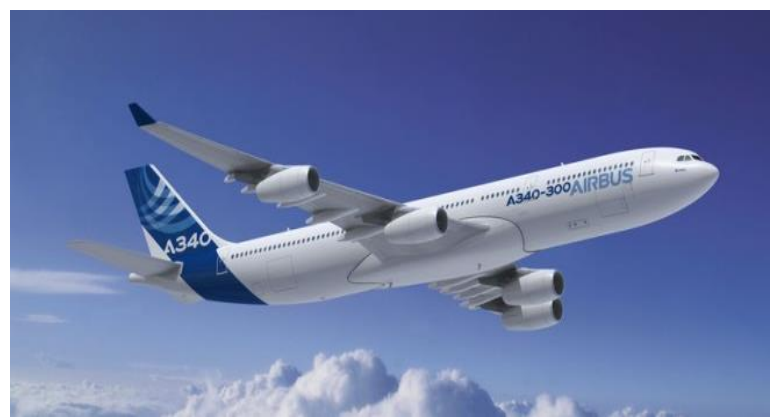

b) A330/340 type Long Range

Fig. 1 Aircraft types 


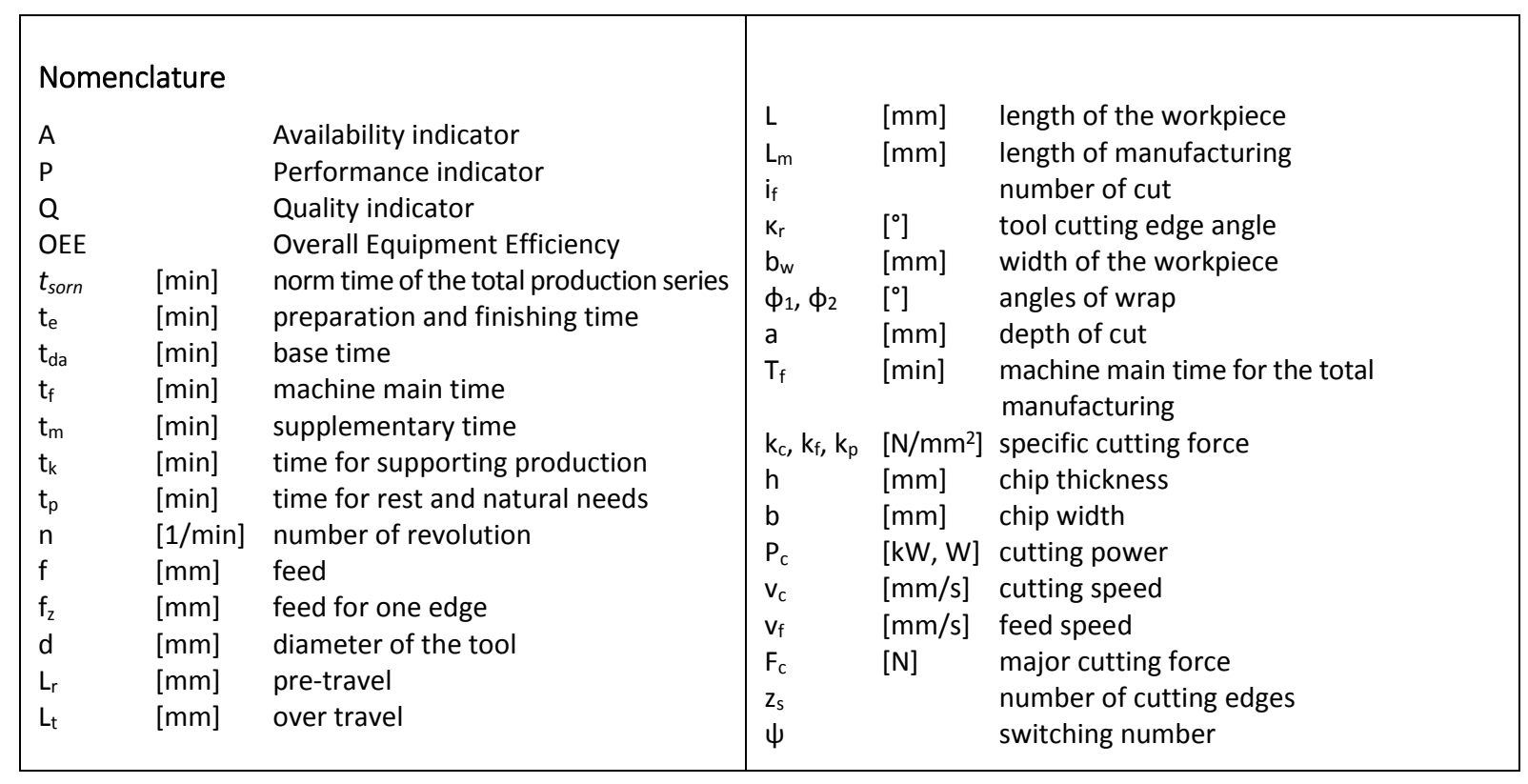

Diehl Aircabin Hungary Ltd. (9. Ipari street, Nyírbátor) is the first and only subsidiary of Diehl Aircabin GMbh located in Laupheim, and through its parent company, this company is a member of the Diehl AeroSystems. In Nyírbátor, there are more than 400 labourers working for the company. The aim is to have 550 labourers until 2018.

At Diehl Aircabin Hungary Ltd. doors - doorframes, side elements, climatic tubes for Single Aisle (shortterm travel) and Long Range (long-term travel) airplane types are produced (Figure 1). Other products are isolation packages for Airbus aircrafts

\section{Maka type $\mathrm{CNC}$ driven milling machine having 5 axes}

At Diehl Aircabin Hungary Ltd. there is a MAKA M7t type CNC driven milling machine having 5 axes (Figure 2). The overall dimension of the machine: $5.2 \mathrm{~m} \times 9.2 \mathrm{~m} \times 6.2 \mathrm{~m}$. Year of its production: 2015 .

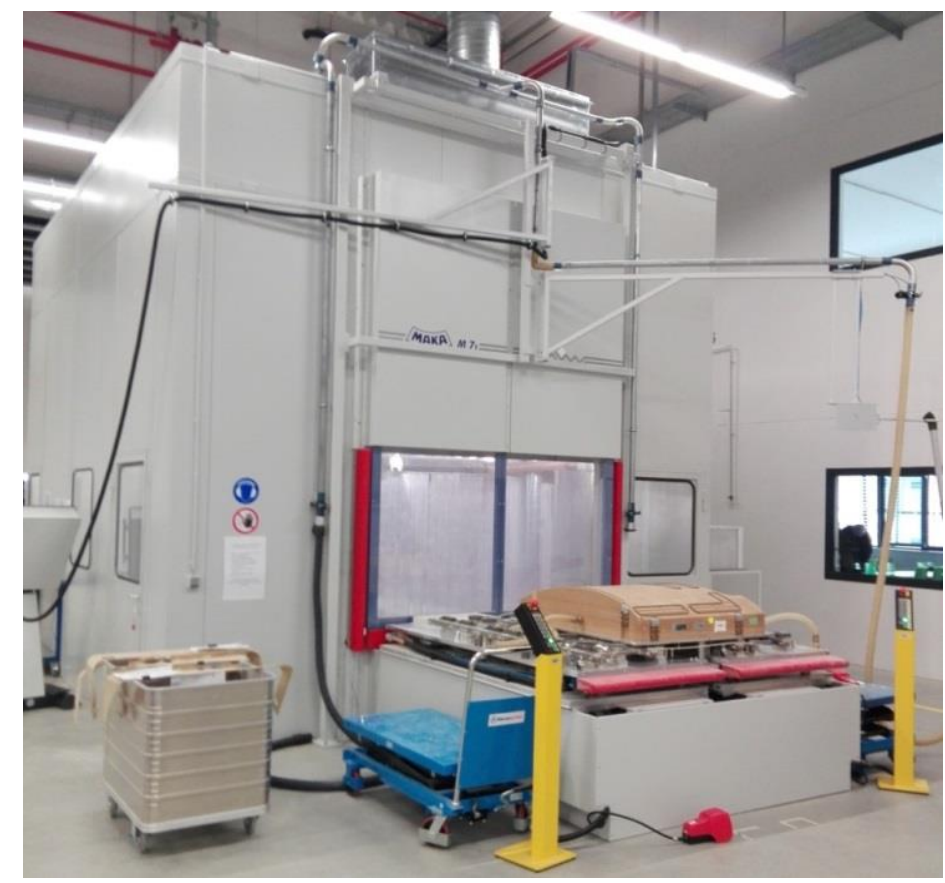

Fig. 2 MAKA M7t type CNC driven milling machine [1] 


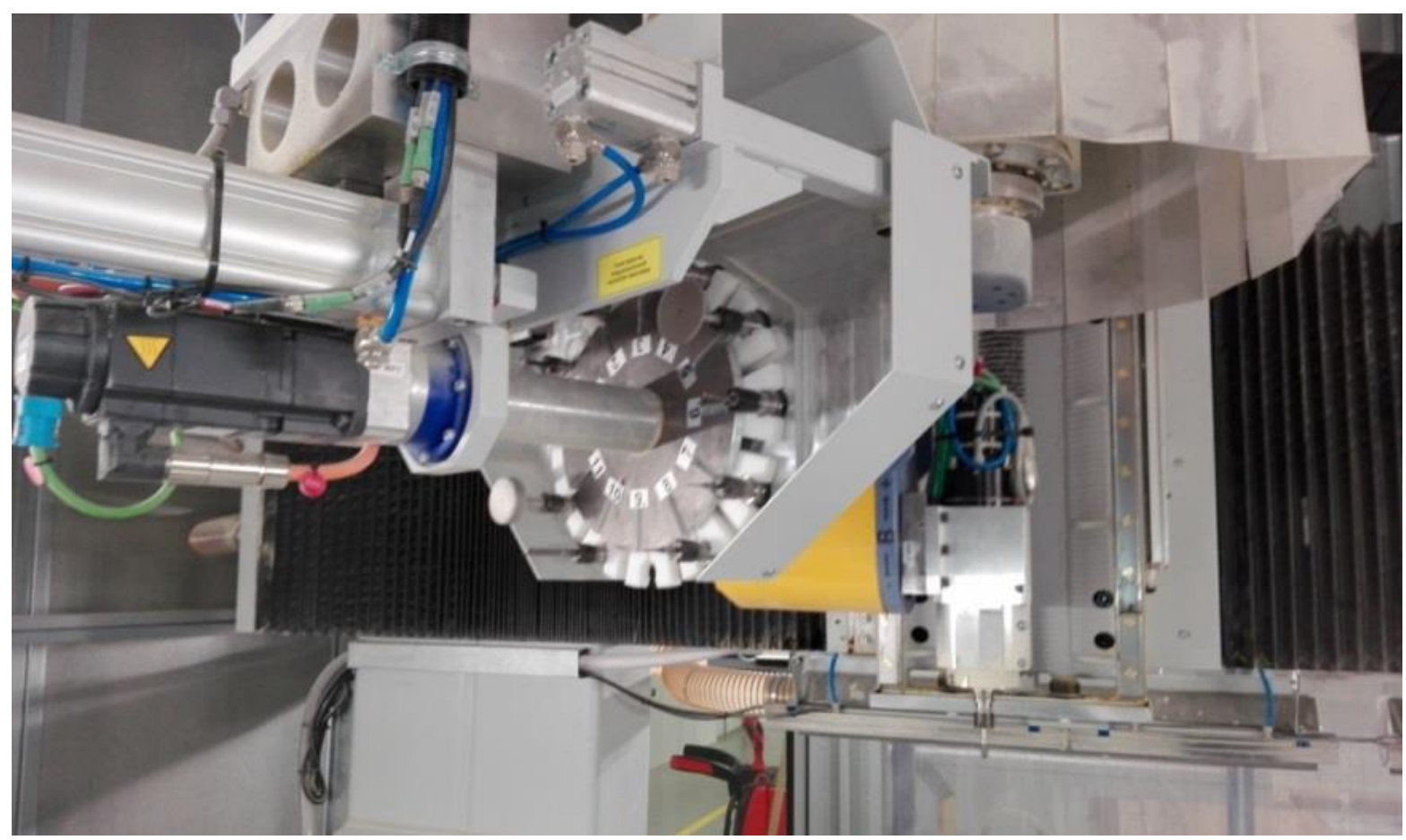

Fig. 3 Main spindle and the tool storage with 12 tool places

The milling machine has 2 work tables. Because of this, manufacturing activity and the fixing of the workpiece can be paralleled (Figure 2) [1]. If we would like to use more than one tool, the automatic tool change system can change tool and it is possible to fix 12 tools in the tool storage system. (Figure 3) [1], [2].

\section{The calculation of OEE indicator}

The OEE (Overall Equipment Efficiency) value shows percentage of the amount of the products are produced, of which the machine is being capable under optimal circumstances [4], [5] (Figure 4). OEE indicator is formed by 3 factors [5]:

- The indicator of availability $(A)$ refers to those time losses when the equipment could produce but due to some reasons it does not work. The losses that influence this factor: malfunction, change over time, and the time of tool change.

- Performance indicator (P) includes those losses when the machine is operating but it is not producing at all or not producing with the appropriate amount. The sources of losses, which influence this factor: micro shut downs, loss of speed.

- Quality indicator (Q): the equipment is running, producing but the product cannot be used because its quality is not appropriate. The sources of losses, which influence this factor: quality loss, start up loss. 


\section{Total operating time}

\section{A Available time}

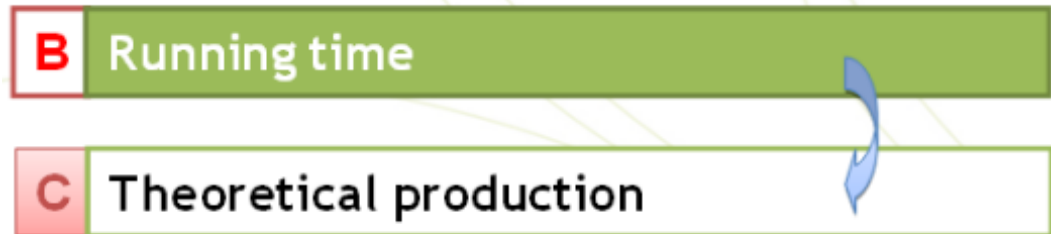

\section{Real production}

Minor Stops

Speed loss

\section{E Real production \\ F Good products \\ Scrap \\ Rework}

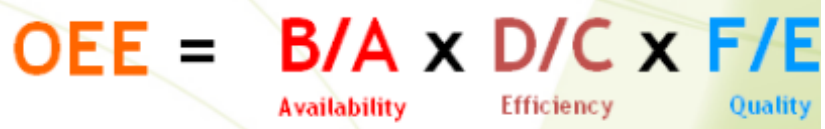

Fig. 4 The background principle of the calculation of the OEE

At Diehl Aircabin Hungary Ltd. OEE indicator is calculated annually for MAKA type CNC milling machine. Sidewalls, doors and doorframes are the products produced by this machine [1]. For calculation the following data are needed:

- number of produced pieces;

- time schedule;

- number of reworked workpieces;

- number of scraps;

- production time;

- unplanned shutdowns.

The total amount is the number of the total produced pieces in the examined period.

The steps of calculation of OEE indicator are the following [4], [5]:

$$
\begin{gathered}
\text { Total amount } \\
+ \text { number of produced pieces }+ \text { number of reworked piecest } \\
+ \text { number of scraps }
\end{gathered}
$$

Indicator of availability $(A)=($ Production time - Unplanned shutdowns $) /$ Production time

Performance indicator $(P)=($ Total amount $x$ Time schedule $) /$ Production time

Quality indicator $(Q)=$ Number of produced pieces $/$ Total amount

$$
O E E=A \cdot P \cdot Q
$$


For 2015 (current state of affairs) based on data available and using the formulas in (1) - (5) the value of OEE indicator has been calculated, which equals $47 \%$. So i.e. MAKA type CNC milling machine produces $47 \%$ of its number of products, of which it would be capable in optimal case [1].

For 2016 (future state) at Diehl Aircabin Hungary Ltd., customers' needs, number of produced products and their complexity are continuously growing. Based on data available and using the formulas in (1) - (5) the value of OEE indicator has been calculated, which is $159.3 \%$. The calculated OEE indicator is above $100 \%$, which means if there is that high production volume, one MAKA type CNC milling machine will not be sufficient for production. Thus, for this reason 2 machines will be indispensable.

\section{Making a computer program for OEE indicator calculator}

For efficient calculation of OEE indicator, we have made a computer program in MATLAB developer environment. The aim was to ease the work of the company as with the help of the program OEE indicators can be calculated no only annually but also monthly. Input data of the program are the following [1], which should be provided:

1. For how many months or years calculation would be made

2. For which month or years calculation should be made

3. The number of produced items

4. Time schedule expressed in minutes

5. Number of reworked products

6. Number of scraps

7. Production time expressed in minutes

8. Unplanned shutdowns expressed in minutes

After all, the program calculates the following values below, shows them on the screen and saves in a different file [1]:

- Total quantity;

- Availability indicator;

- Performance indicator;

- Quality indicator;

- OEE indicator;

- OEE indicator in \%;

- Number of machines needed for production.

The program draws 8 functions, which are the following (Figure 5) [1]:

- Month or year - Number of produced pieces;

- Month or year - Time schedule;

- Month or year - Number of reworked pieces;

- Month or year - Number of scraps;

- Month or year - Production time;

- Month or year - Unplanned shut downs;

- Month or year-Total quantity;

- Month or year - OEE indicator diagram. 

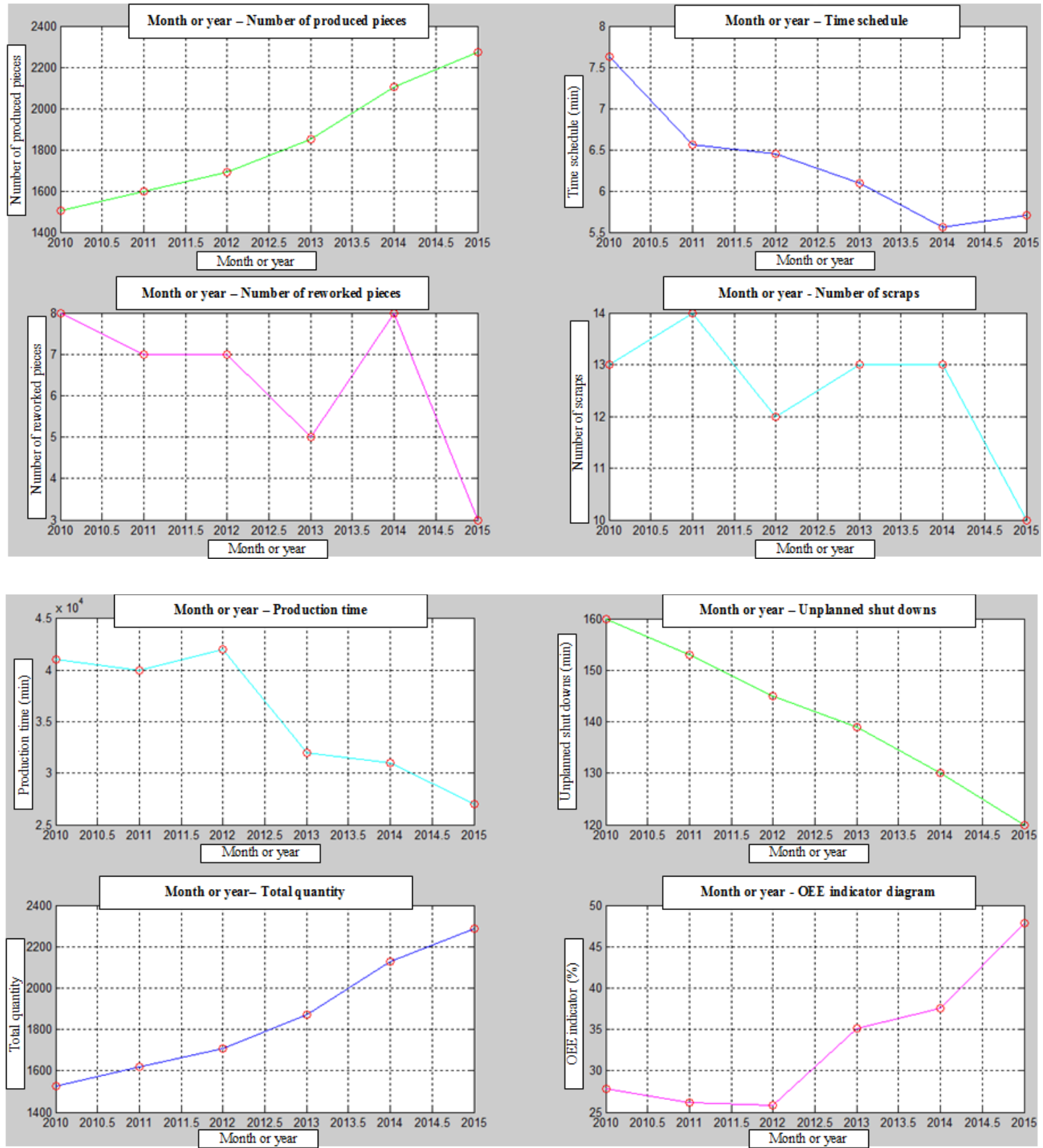

Fig. 5 Output functions of the computer program

\section{Defining the production main time}

Possible main production operations are defined on the machine (drilling, milling) and their main machine time, in general, in relation to the technological parameters. Figure 6 shows the structure of norm time of total production series. 


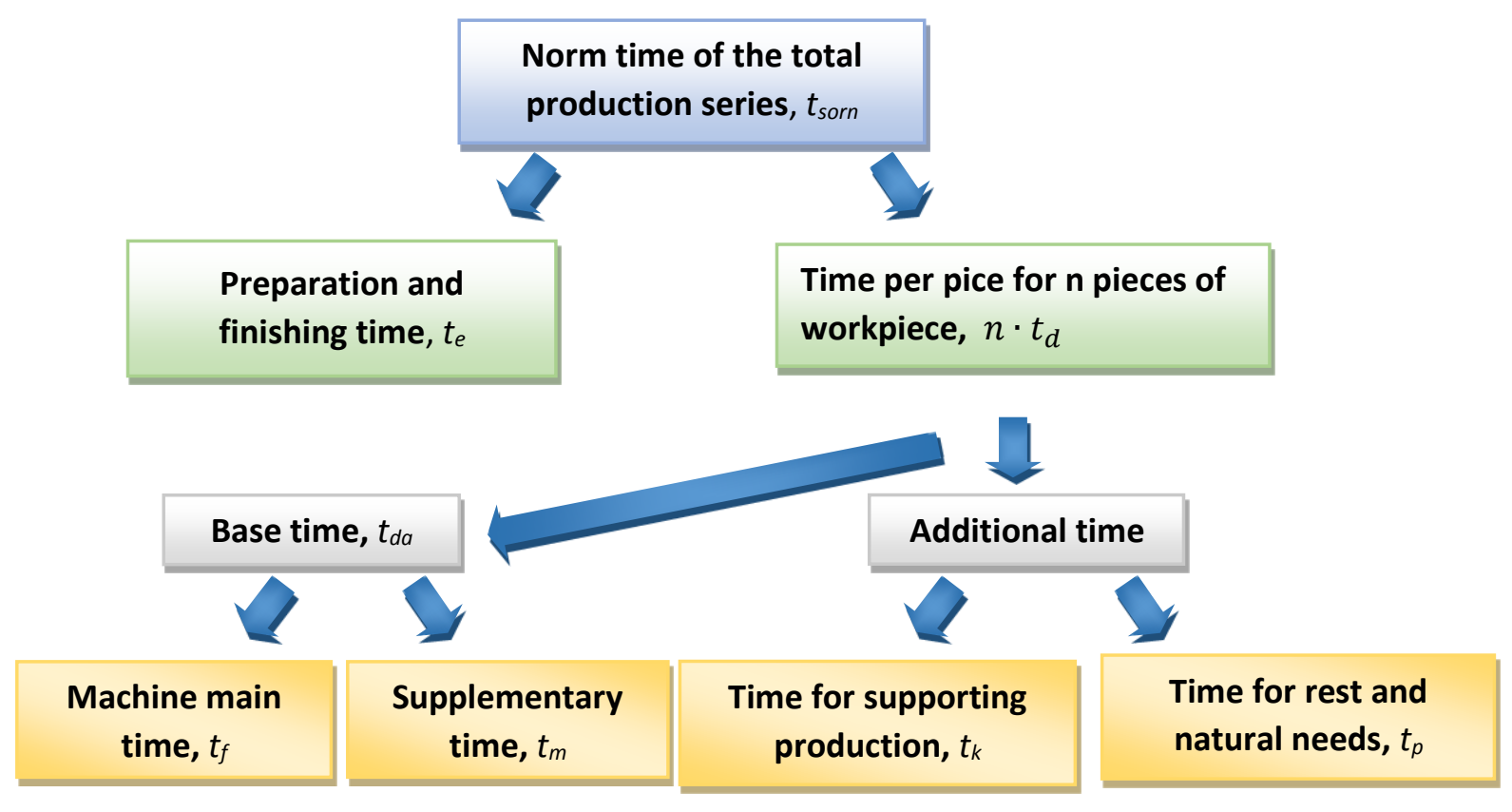

Fig. 6 The structure of norm time of the total production series

The machine main time $(t f)$ is a part of the base time during which the shaping occurs directly on the workpiece.

The supplementary time $(\mathrm{tm})$ is a part of the base time which is only indirectly necessary for the completion of the manufacturing task. It is repeated on every workpiece. For example, workplace clamping.

The most general equation for the time of producing one item (Figure 6) [3], [7], [8], [9], [10], [11]:

$$
t_{d}=t_{f}+t_{m}+t_{k}+t_{p}
$$

Defining the duration of the operation elements [3], [7], [8], [9], [10], [11]:

$$
t_{f g}=i_{f} \cdot \frac{L}{n \cdot f}=i_{f} \cdot \frac{L}{v_{f}}
$$

\subsection{Determination of the machine main time in case of turning}

The turning is continuous cutting with circle shaped chip and arbitrary feed motion which is perpendicular for the cutting direction. Its tool is lathe machine (Figure 7). The isolated chip is usually constant sectional. The cutting of this is occurring continuously [3], [8], [12], [13], [14]. 


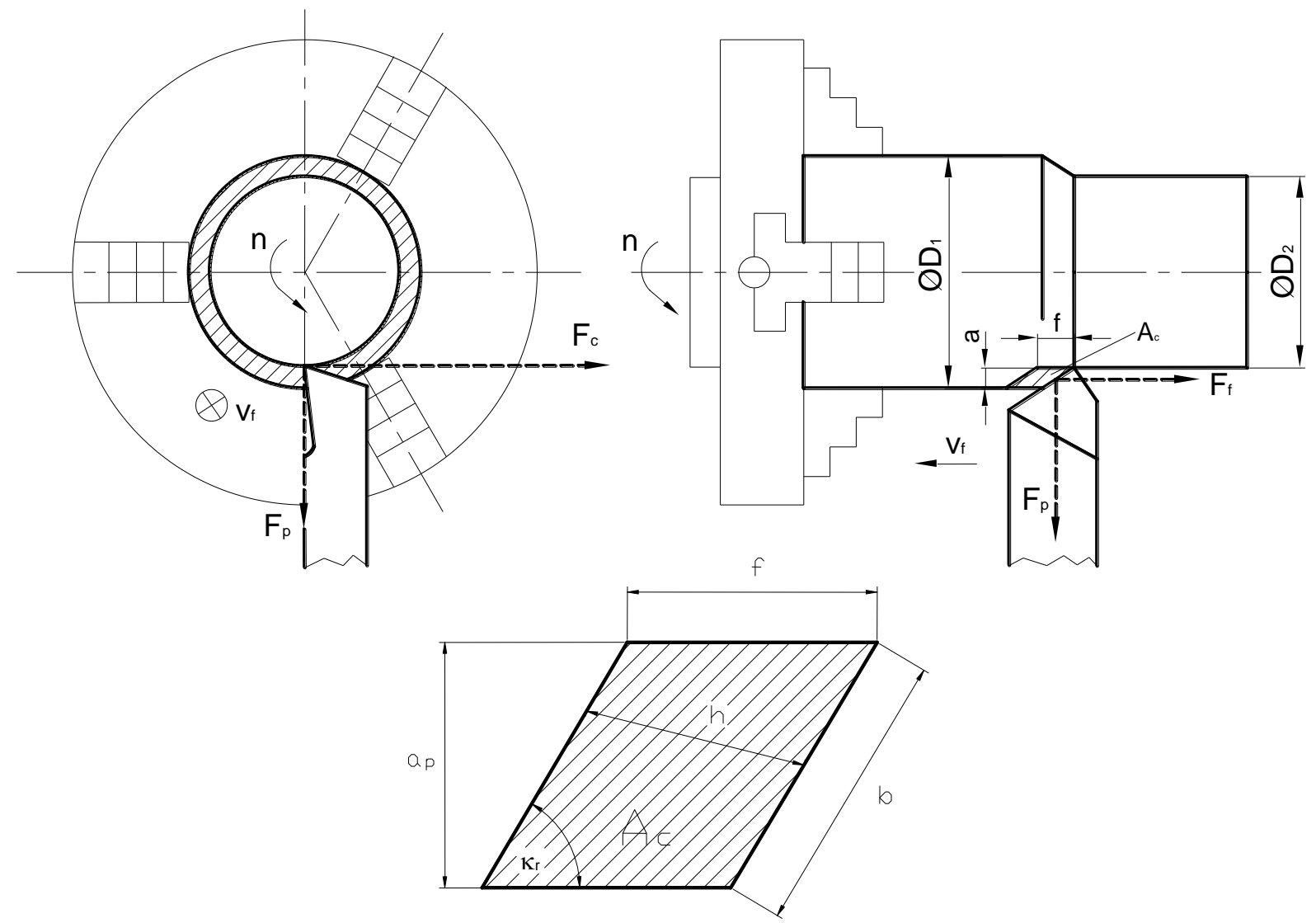

Fig. 7 The theorem of turning technology

The specific cutting force is written for the three force components (Figure 7) [3], [7], [12], [13]:

$$
\left.\begin{array}{l}
F_{c}=k_{c} \cdot A_{c} \\
F_{f}=k_{f} \cdot A_{c} \\
F_{p}=k_{p} \cdot A_{c}
\end{array}\right\}
$$

The territory of the chip section (Figure 7) [3], [7], [12], [13]:

$$
A_{c}=a_{p} \cdot f=b \cdot h
$$

where

$$
\begin{aligned}
& h=f \cdot \sin \kappa_{r} \\
& b=\frac{a_{p}}{\sin \kappa_{r}}
\end{aligned}
$$

The formula of the cutting power is

$$
P_{c}=F_{c} \cdot v_{c}
$$

In Figure 8 a thread cutting manufacturing process could be an example. The numbers (1 -6) are nominated as the manufacturing steps. The aim is to calculate the total machine time. The machine times of every manufacturing steps must be added. 


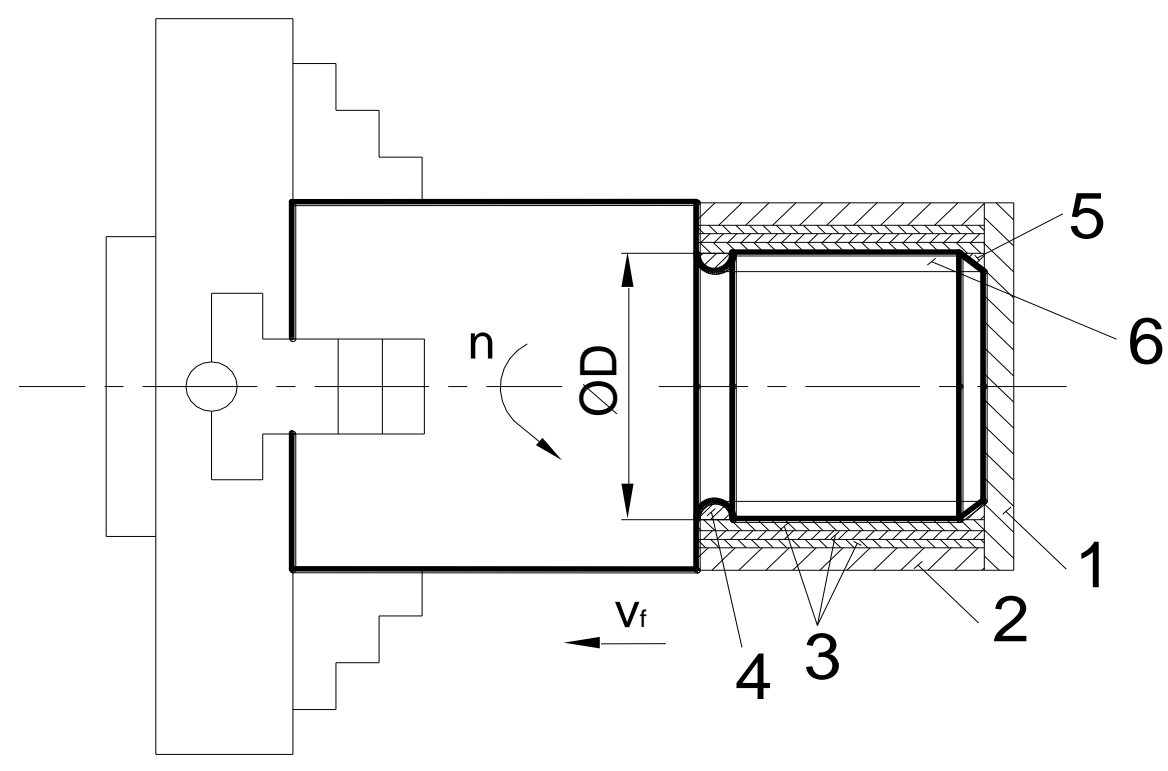

Fig. 8 Determination of the machine time in case of thread cutting

The total machine time is

$$
\mathrm{t}_{\mathrm{fg}}=\frac{\mathrm{L}_{1}}{\mathrm{n}_{1} \cdot \mathrm{f}_{1}}+\frac{\mathrm{L}_{2}}{\mathrm{n}_{2} \cdot \mathrm{f}_{2}}+3 \cdot \frac{\mathrm{L}_{3}}{\mathrm{n}_{3} \cdot \mathrm{f}_{3}}+\frac{\mathrm{L}_{4}}{\mathrm{n}_{4} \cdot \mathrm{f}_{4}}+\frac{\mathrm{L}_{5}}{\mathrm{n}_{5} \cdot \mathrm{f}_{5}}+2 \cdot \frac{\mathrm{L}_{6}}{\mathrm{n}_{6} \cdot \mathrm{f}_{6}}
$$

The time of the thread cutting manufacturing step depends on the thread cutting strategy (Figure 9).

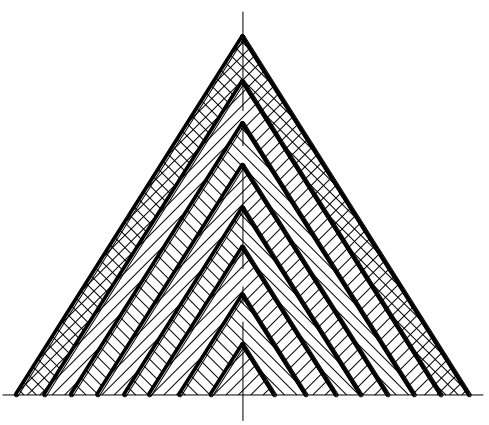

a) radial or symmetrical

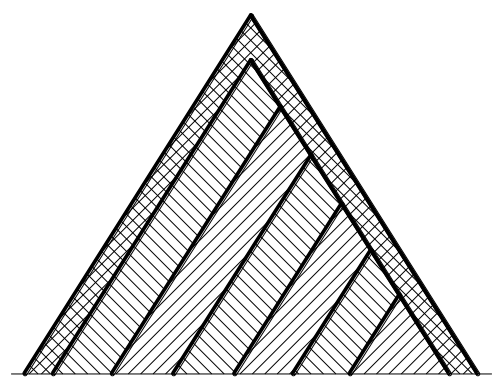

b) one sided

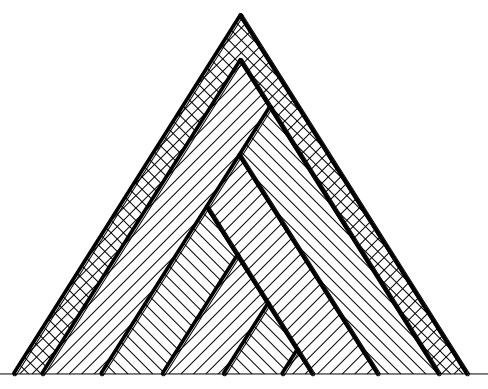

c) two sided or edge changing

Fig. 9 Designing of cutting processes in case of thread cutting technology [14]

In case of radial or symmetrical thread cutting process (Figure 9.a) the two cutting edges of the cutting tool are loaded equally. The machine main time will be long.

In case of one sided thread cutting process (Figure 9.b) only one cutting edge is loaded that is why this cutting edge will be wearing. The machine main time will be lower than the radial or symmetrical process.

In case of two-sided thread cutting process (Figure 9.c) two cutting edges are loaded. The direction of the cutting tool always changes. 


\subsection{Calculation of the machine main time for drilling}

During drilling or counterbore technology interior cylindrical surfaces or other interior formed surfaces (cone - shaped, threaded, etc.) are manufactured. The cutting motion is rotation motion which are done by the tool or workpiece [3], [7], [8], [9], [12], [13], [14].

The feed motion is also done by the tool or workpiece. The depth of cut is determined by the dimension of the cutting tool.

The technological figures of drilling and counterbore technologies could be seen in Figure 10 [3], [7], [8], [9], [12], [13], [14].

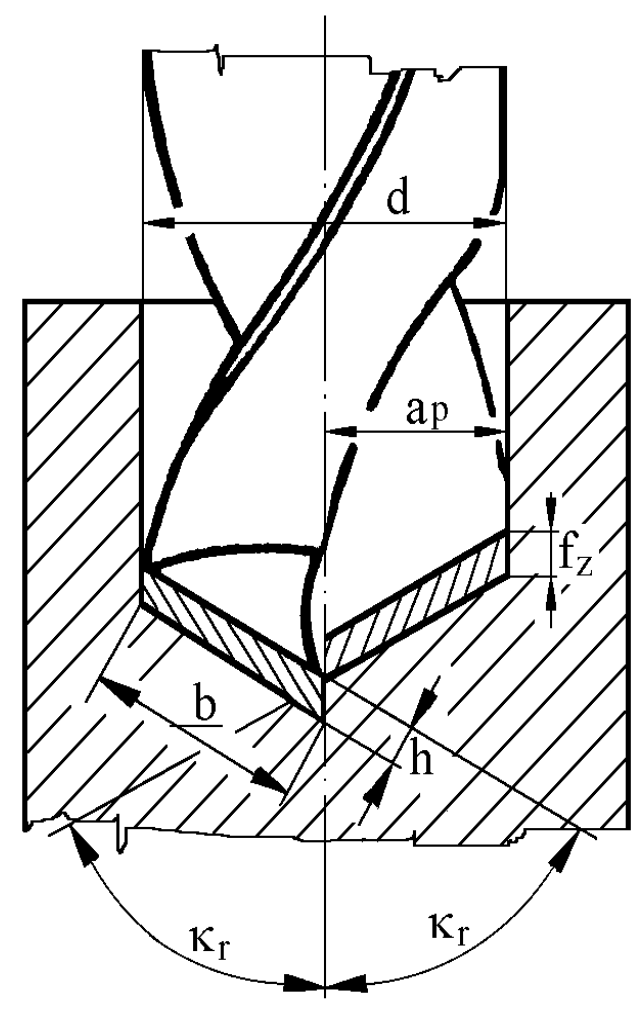

a) drilling technology

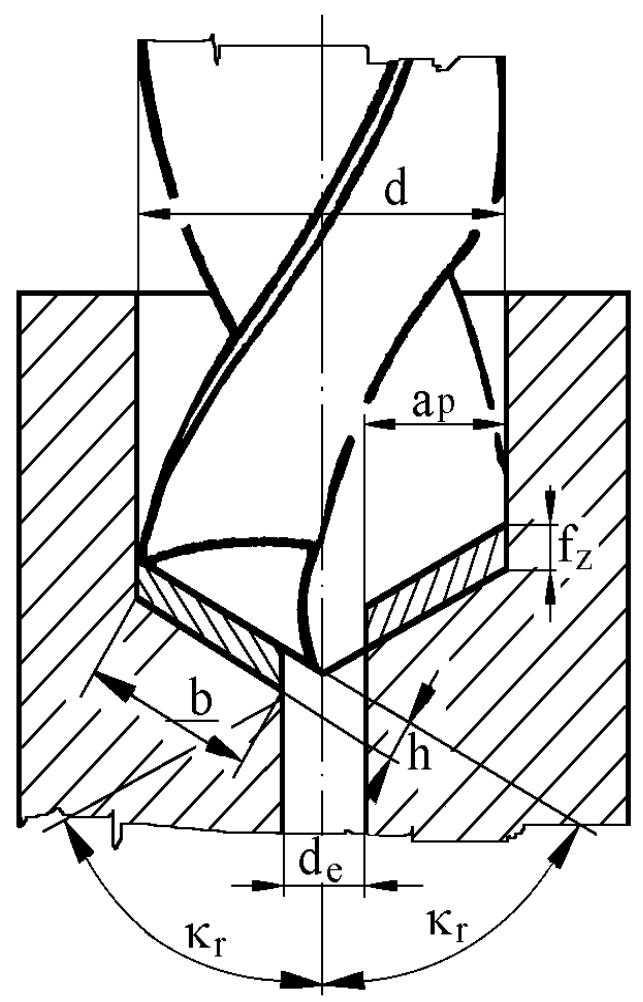

b) counterbore technology

Fig. 10 The theorem of drilling and counterbore technologies [3], [13]

The territory of the chip section in case of drilling technology (Figure 10.a) [3], [7], [8], [13]:

$$
A_{c}=a_{p} \cdot f_{z}=\frac{d}{2} \cdot \frac{f}{z_{s}}=b \cdot h
$$

The territory of the chip section in case of counterbore technology (Figure 10.b) [3], [7], [8], [13]:

$$
A_{c}=a_{p} \cdot f_{z}=\frac{d-d_{e}}{2} \cdot \frac{f}{z_{s}}=b \cdot h
$$

The cutting force for one edge in case of drilling technology (Figure 11):

$$
F_{c z}=k_{c} \cdot A_{c}=k_{c} \cdot f_{z} \cdot a_{p}=k_{c} \cdot \frac{d \cdot f}{4}
$$




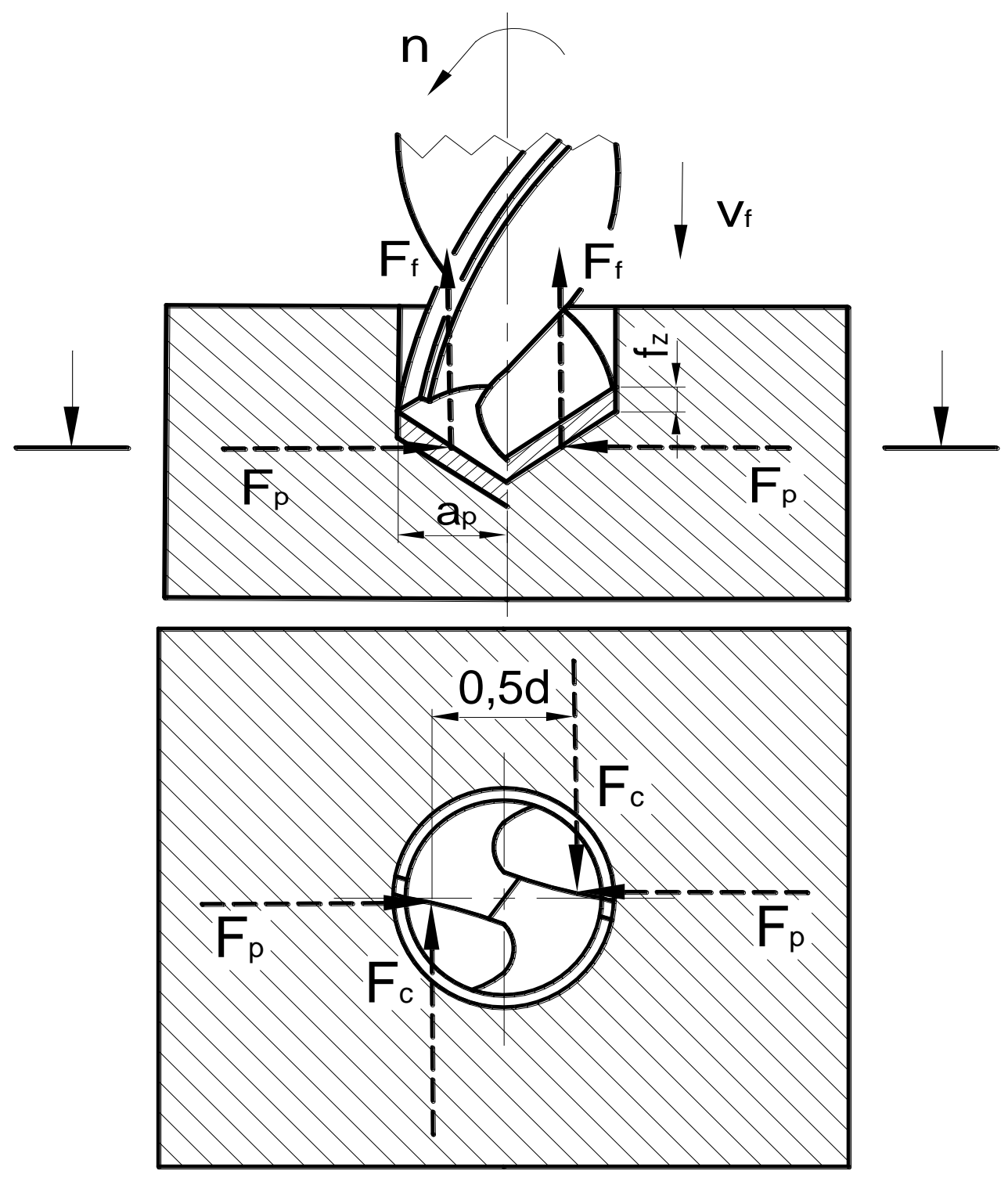

Fig. 11 The components of cutting force on the cutting edge of the twist drill

The necessary moment for drilling (Figure 11):

$$
M_{c}=F_{c} \cdot 0,5 \cdot d=k_{c} \cdot \frac{d^{2} \cdot f}{8}
$$

The cutting force for one edge in case of counterbore technology (Figure 12):

$$
F_{c z}=k_{c} \cdot A_{c}=k_{c} \cdot f_{z} \cdot a_{p}=k_{c} \cdot \frac{\left(d-d_{0}\right) \cdot f}{4}
$$

The necessary moment for counterbore technology (Figure 12):

$$
M_{c}=k_{c} \cdot f \cdot \frac{d^{2}-d_{0}^{2}}{8}
$$



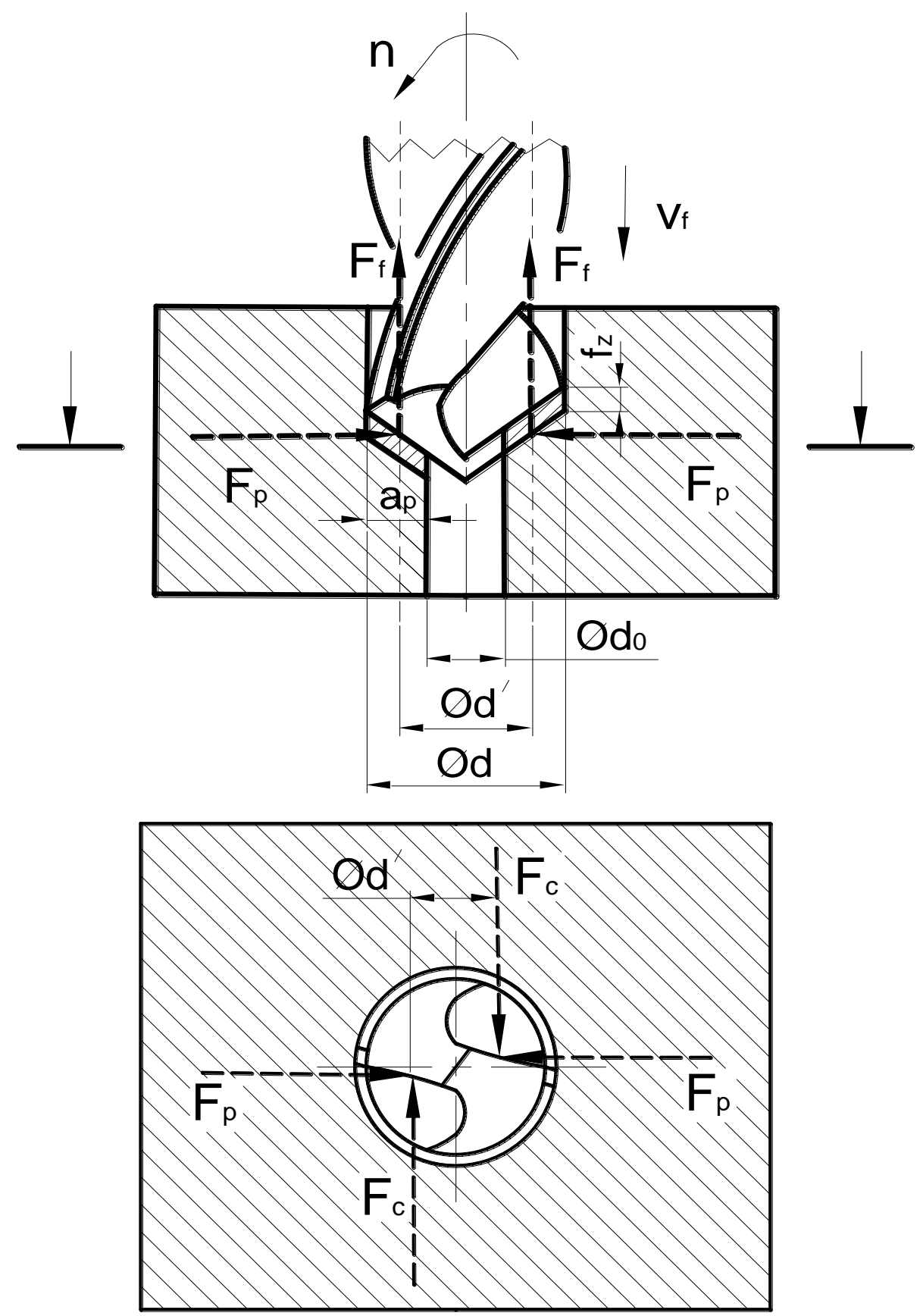

Fig. 12 The components of cutting force in case of counterbore technology

Based on Figure 13, drilling length is:

$$
L_{f}=L_{r}+L+L_{t}+\frac{d}{2 \cdot \operatorname{tg} \kappa_{r}}
$$

Machine main time based on (15) and (7):

$$
T_{f}=\frac{L_{r}+L+L_{t}+\frac{d}{2 \cdot \operatorname{tg} \kappa_{r}}}{n \cdot f}
$$




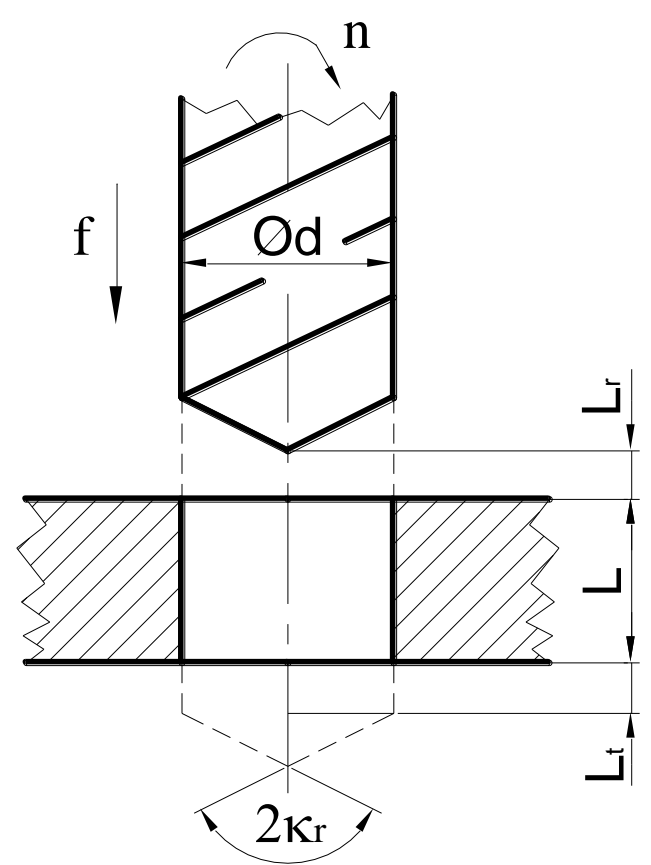

Fig. 13 Defining drilling length

\subsection{Calculation of machine main time for technology of plain milling}

In case of plain milling the cutting motion is done by the tool and the feed motion is done by the workpiece.

The rotation axis of the hob is parallel with the milled surface. It is crucial. The machined surface is plane but it could be cylindrical or shaped in rare cases [3], [7], [8], [10][9], [12], [13], [14].
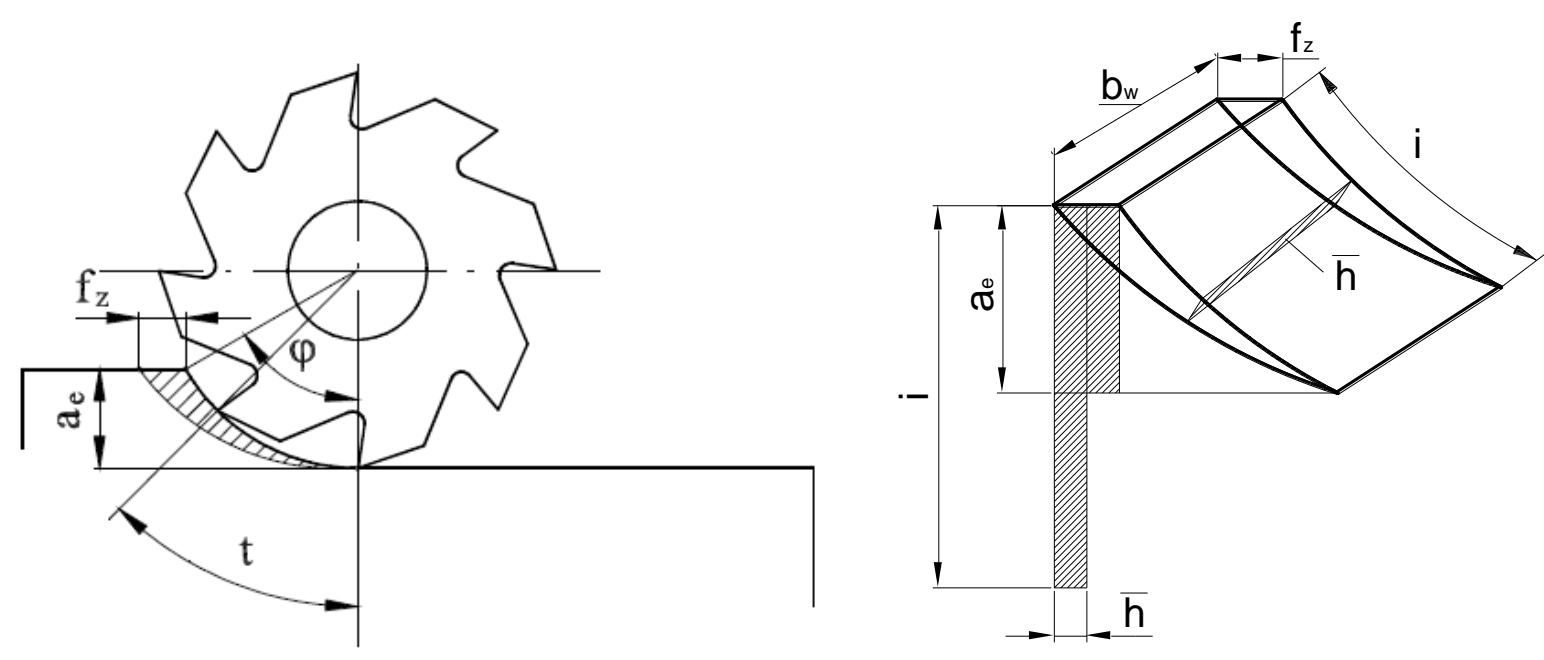

Fig. 14 Determination of the technological parameters in case of plain milling $[3,13]$

The cutting force for one edge of the tooth of the milling cutter [3], [7], [8], [13]:

$$
F_{c 1}=k_{c} \cdot A_{c 1}=k_{c} \cdot b_{w} \cdot h
$$


Considering the $\psi$ switching number the total cutting force could be calculated:

$$
F_{c}=\Psi \cdot F_{c 1}
$$

During cutting the switching number is expressed by the number of the tooth of milling cutter [3], [12], [13], [14]:

$$
\Psi=\frac{i}{t} \approx \frac{p}{t}=\frac{z \cdot \sqrt{a \cdot d}}{d \cdot \pi}=\frac{z}{\pi} \cdot \sqrt{\frac{a}{d}}
$$

Based on (17), (18) and (19) the total cutting force is

$$
F_{c}=k_{c} \cdot a \cdot f_{z} \cdot b_{w} \cdot \frac{z}{d \cdot \pi}
$$

The cutting power is [3], [7], [8], [13]

$$
P_{c}=\frac{k_{c} \cdot a \cdot b_{w} \cdot v_{f}}{60 \cdot 10^{6}}(k W)
$$

Based on Figure 15, the length of milling is:

$$
L_{m}=L_{t}+L+L_{r}
$$

Based on (22) and (7) the machine main time is:

$$
T_{f}=i_{f} \cdot \frac{L_{m}}{v_{f}}=i_{f} \cdot \frac{L_{t}+L+L_{r}}{n \cdot f}
$$

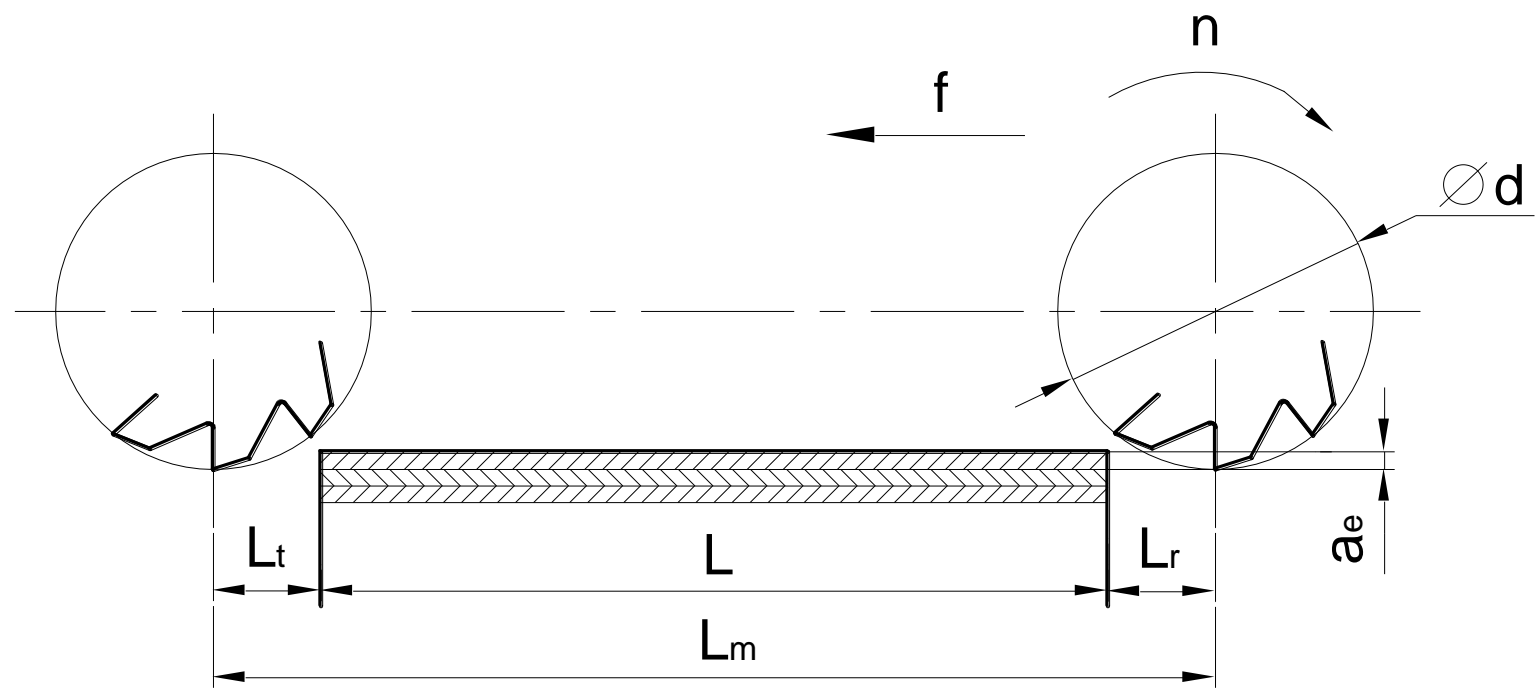

Fig. 15 Determining milling length for plain milling 


\subsection{Calculation of machine main time for face milling}

In case of face milling the cutting motion is done by the tool and the feed motion is done by the tool or workpiece [3], [6], [7], [8], [12], [13], [14].

The rotation axis of the milling cutter is perpendicular for the milled surface. The machined surface is mainly planar surface.

The chip section is changing along the cutting path of the tooth of the milling cutter: the lowest is on the place of the entrance and the exit. The highest is on the symmetric plane of the feed direction of the axis of the milling cutter.

The $f_{z}$ feed for one edge is the most important parameter of the face milling. The $f_{r \varphi}$ is the radius directional feed [3], [6], [7], [8], [12], [13], [14].

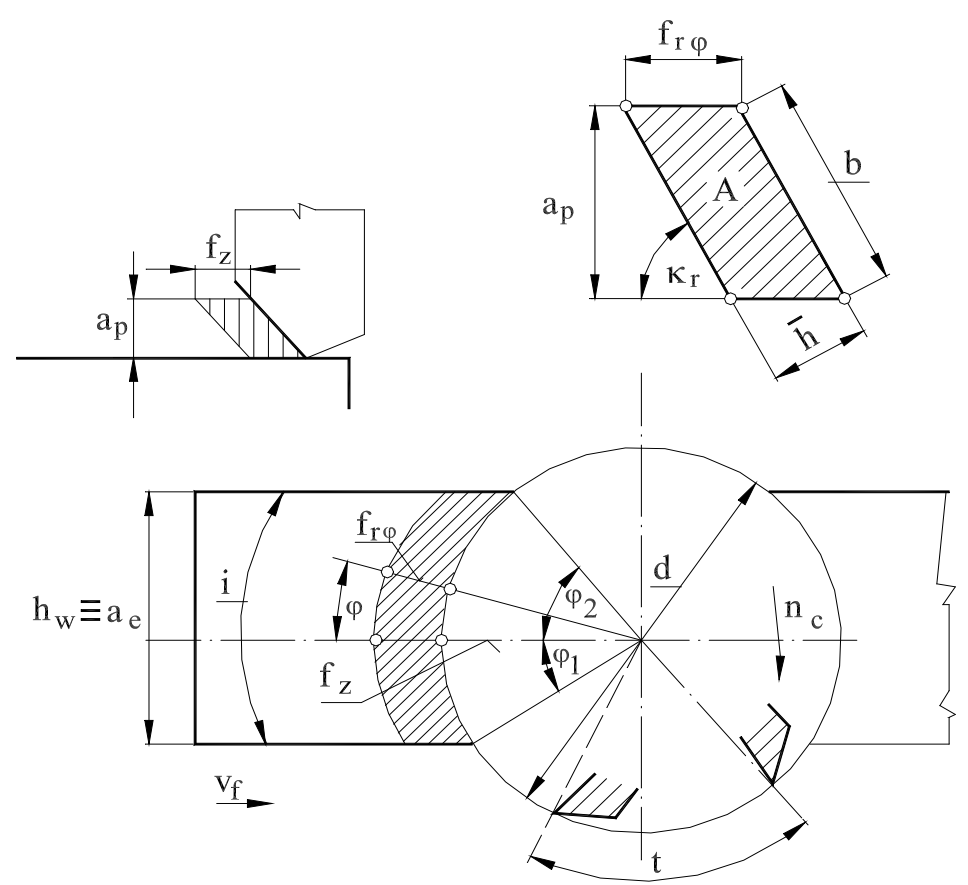

Fig. 16 The technological parameters in case of face milling [3], [13]

The cutting force for one edge of the tooth of the milling cutter (Figure 16) [3], [13]:

$$
F_{c 1}=k_{c} \cdot a \cdot f_{z} \cdot b_{w} \cdot \frac{360^{\circ}}{d \cdot \pi \cdot\left(\varphi_{1}+\varphi_{2}\right)^{\circ}}
$$

Considering the switch number the total cutting force is (Figure 16) [3], [12], [13], [14]

$$
F_{c}=\sum_{i=1}^{z} F_{c 1}=\Psi \cdot F_{c 1}
$$

The switching number is (Figure 16) [3], [12], [13], [14]

$$
\psi=\frac{i}{t}=\frac{d \cdot \pi \cdot\left(\varphi_{1}+\varphi_{2}\right)^{\circ} \cdot z}{360^{\circ} \cdot d \cdot \pi}
$$


Based on (24), (25) and (26) the total cutting force is

$$
F_{c}=k_{c} \cdot a \cdot f_{z} \cdot b_{w} \cdot \frac{z}{d \cdot \pi}
$$

The cutting power is

$$
P_{c}=\frac{k_{c} \cdot a \cdot b_{w} \cdot v_{f}}{60 \cdot 10^{6}}(k W)
$$

Based on Figure 17 the length of milling is:

$$
L_{m}=L_{t}+L+L_{r}+d
$$

Based on (29) and (7) the machine main time is:

$$
T_{f}=i_{f} \cdot \frac{L_{m}}{v_{f}}=i_{f} \cdot \frac{L_{t}+L+L_{r}+d}{n \cdot f}
$$

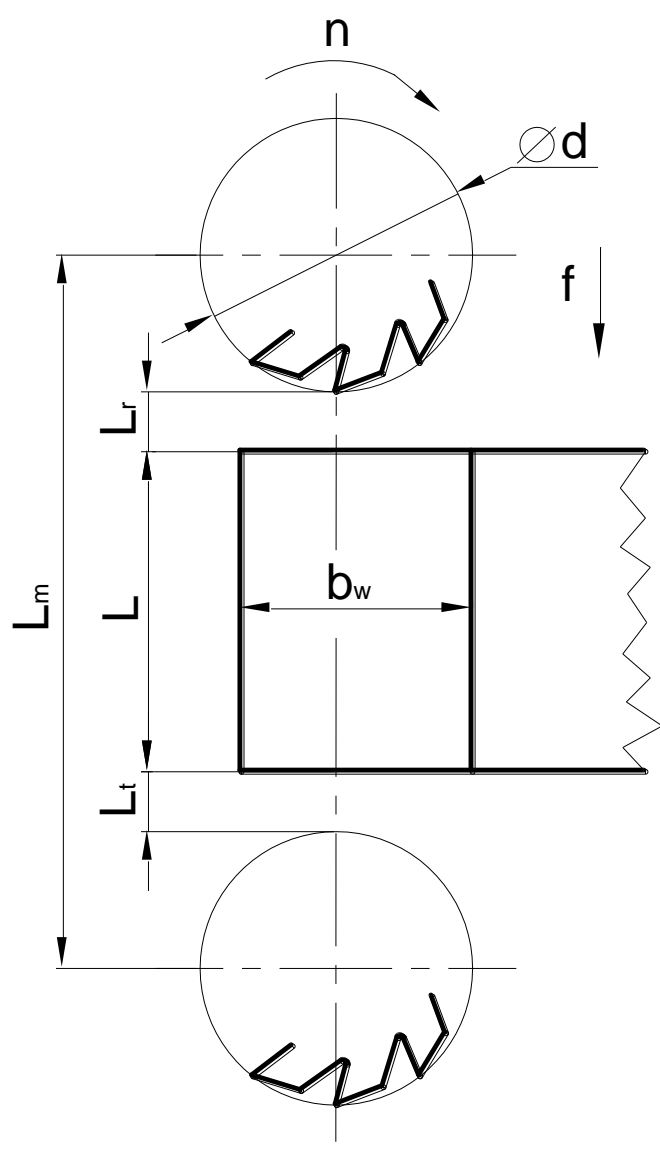

Fig. 17 Defining milling length for face milling

\section{Calculation of machine main time for manufacturing keyway}

Figure 18 shows the technology of manufacturing a keyway. During manufacturing in case of every cut the tool goes into the depth of the keyway with $a_{p}$ value (i.e. depth of cut), then the material is 
peeled along the length of the keyway. Because of these facts there are 2 components that make up the main time of the technology (the component towards the direction of the depth of the cut, the component towards the direction of feeding).
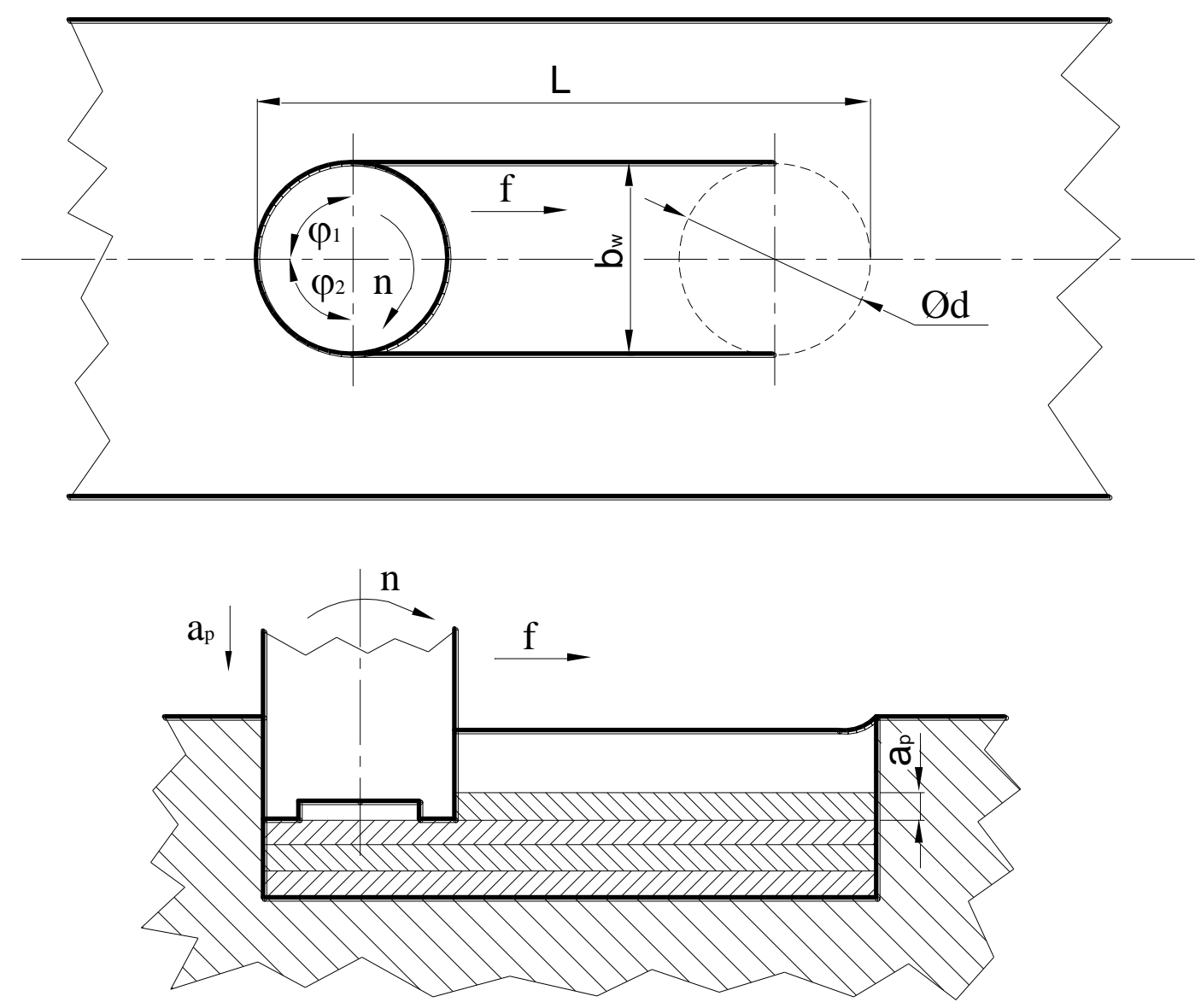

Fig. 18 Technological planning of keyway manufacturing

Based on (7) the main machine time for one cut is (Figure 18):

$$
t_{f}=\frac{L-d}{f_{z} \cdot z \cdot n}+\frac{a_{p}}{f_{z} \cdot z \cdot n}
$$

If $i_{f}$ is the number of cuts, then machine main time of milling of the total keyway is:

$$
T_{f}=t_{f} \cdot i_{f}
$$

\section{The reduction of the machine time}

Exists many methods of reducing of the machine time. This time could be reduced by using of vintage tool, more favourable cooling and lubrication conditions or reduction of the life of a tool. High reduction of the machine time could be reached by the contraction of manufacturing steps (Figure 19 and 20). 


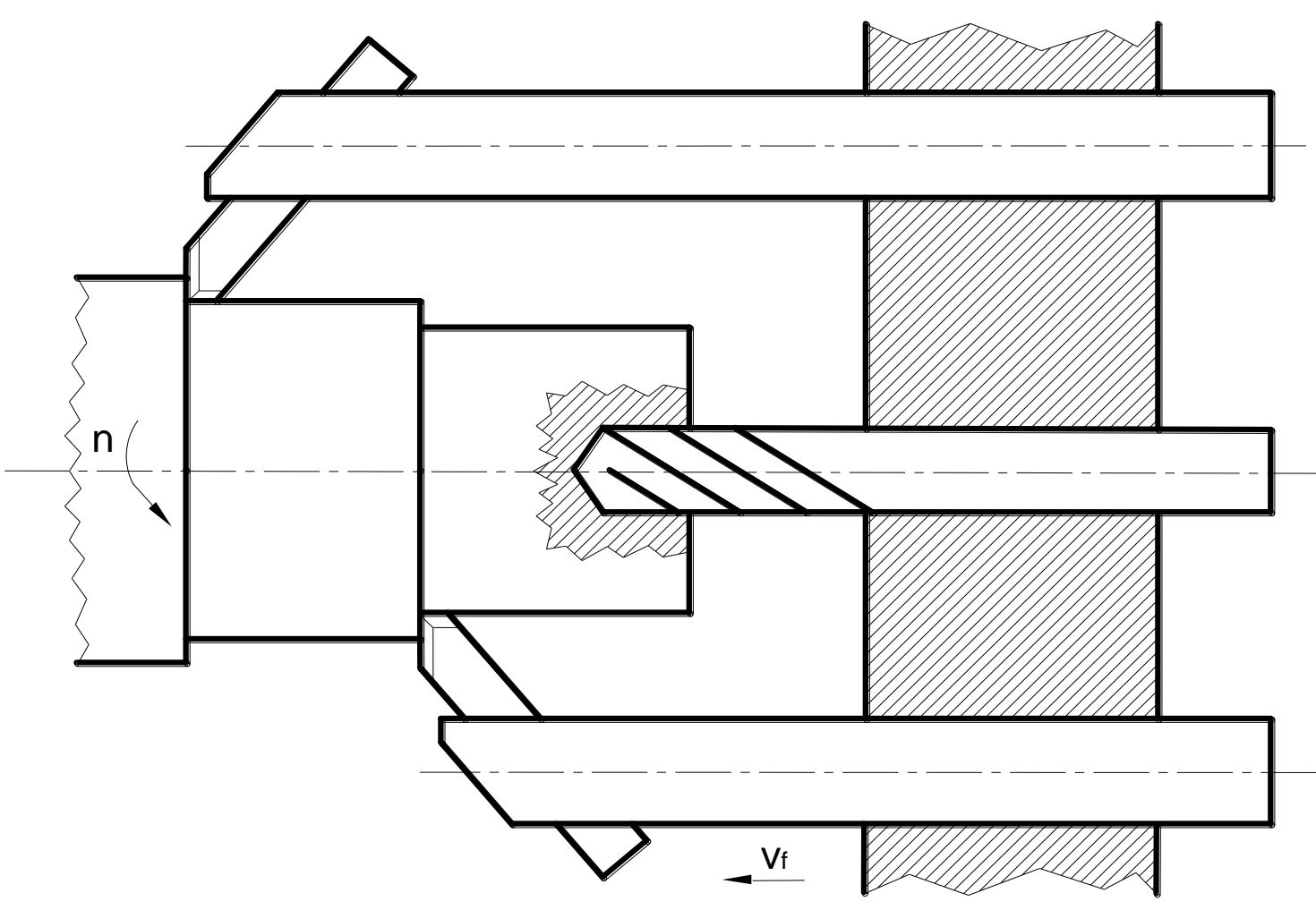

Fig. 19 Contraction of turning and drilling manufacturing steps
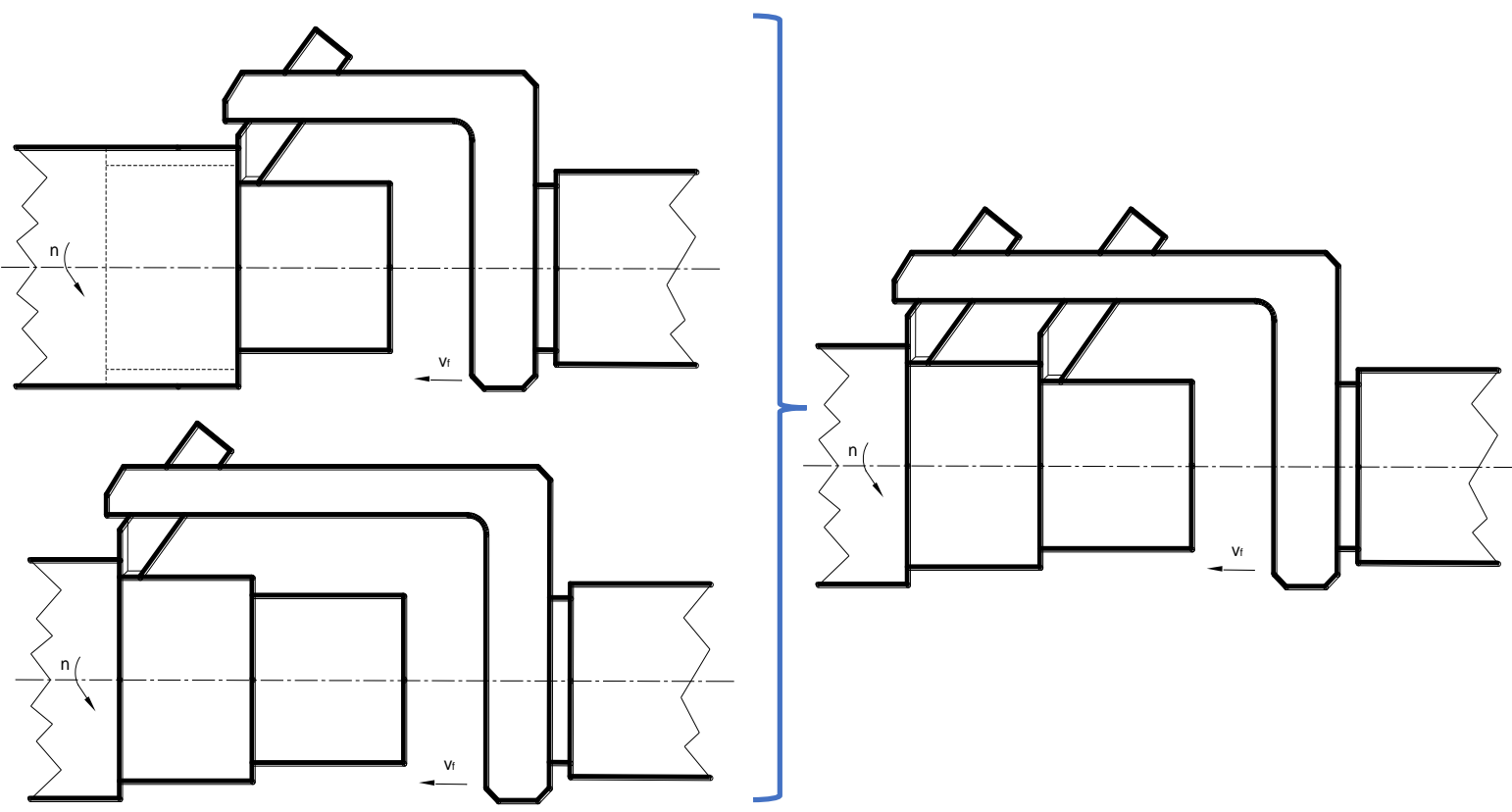

Fig. 20 Contraction of turning manufacturing steps

\section{Conclusion}

We have determined the OEE indicator values for MAKA type CNC driven milling machine having 5 axes found at Diehl Aircabin Hungary Ltd. for the period of 2015 and 2016. 
The results have shown that the utilization of the machine is $47 \%$ in 2015 . Although for making calculation for 2016, we obtained result that 2 CNC milling machines will be necessary for producing the estimated number of products.

We have developed a computer program for the analysis and calculation of the OEE indicator. With the help of our computer program, OEE indicator values for any types of machine can be calculated easily and fast. This will facilitate the activity of the company.

Machine main time for the main technological operations on the milling machine have been determined. During production to optimise the machine main times, the right technological parameters (feeding, depth of cut, rotational speed etc.) should be chosen.

Due to these, a higher number of produced items during a given period could be obtained. Based on machine main times, norm time of the total production series can be planned.

\section{Acknowledgement}

The work/publication is partly supported by the EFOP-3.6.1-16-2016-00022 project. The project is co-financed by the European Union and the European Social Fund.

\section{References}

[1] S. Bodzás, Gyártástervezés MAKA típusú CNC vezérlésü 5 tengelyes marógépre, thesis, LEAN profession, University of Debrecen, Debrecen, p. 67., 2016.

[2] M. Berta, CNC szerszámgépek szerszámrendszerei, Collage of Nyíregyháza Publisher, Nyíregyháza, p. 155, ISBN 9786155545030

[3] I. Dudás, Gépgyártástechnológia I., A gyártástechnológia alapjai, 2. edition, Műszaki Könyvkiadó Ltd., Budapest, p. 584, ISBN 963-16-4030-2, 2011.

[4] N. Mátrai, Lean Menedzsment presentations, University of Debrecen, Debrecen, 2016.

[5] GY. Péczely, CS. Péczely, GY. Péczeli, Lean 3, Termelékenységfejlesztés egységes rendszerben, A. A. Stádium Diagnosztikai és Menedzsment Ltd., Budapest, p. 690, ISBN 978-963-08-3163-5, 2009.

[6] L. Wilson, How to implement Lean Manufacturing, Second Edition, p. 419, ISBN 978-0-07183573-2, 2015.

[7] L. Bálint, A forgácsoló megmunkálás tervezése, 2. kiadás, Műszaki Könyvkiadó Kft., Budapest, p. 883, 1961.

[8] F. Klocke, Manufacturing Processes I, Cutting, RWTH Edition, RWTH Aachen University, p. 524, ISBN 978-3-642-11978-1, 2011.

[9] J. A. Schey, Introduction to Manufacturing Processes, McGraw - Hill Book Company, p. 392., ISBN 0-07-055274-6, 1977.

[10] J. G. Bralla, Handbook of Manufacturing Processes, First Edition, Industrial Press Inc., New York, 2007, ISBN 0-831 1-3179-9

[11] H. A. Youssef, H. El hofy, Machining Technology, Machine tools and operations, CRC Press, United States of Amerika, p. 672, ISBN 978-1-4200-4339-6

[12] L. Fridrik, Forgácsolás I. (Forgácsoláselmélet), Miskolci Egyetemi Kiadó, p. 205., 2011.

[13] K. Gyáni, Gépgyártástechnológia alapjai l., Tankönyvkiadó, Budapest, p. 128., 1980.

[14] J. Bali, Forgácsolás, Tankönyvkiadó, Budapest, p. 538., 1988. 